\title{
Why Trusting Nigeria Centre for Disease Control Information Is Difficult: A Study of The Awareness, Knowledge and Perceptions of Nigerians Hesitant Towards COVID-19 Management by NCDC in Nigeria
}

\author{
Mohammed Abdullateef ${ }^{1}$, Beatrice Okonkwo ${ }^{1}$
}

${ }^{1}$ Nile University of Nigeria

Plot 681, Cadastral Zone C-00, Research \& Institution Area, Jabi Airport Bypass, Abuja FCT, 900001, Nigeria

DOI: 10.22178/pos.70-11

LCC Subject Category: BD95-131

Received 20.04.2021

Accepted 27.05.2021

Published online 31.05.2021

Corresponding Author:

Mohammed Abdullateef

muhammedabdul@nileuniversity.edu.ng

(c) 2021 The Authors. This article is licensed under a Creative Commons Attribution 4.0 License @) (1)

\begin{abstract}
As the world battles the novel Coronavirus pandemic ravaging lives and destroying economies, many nations have entrusted the detection, handling and management of confirmed coronavirus cases to their leading public health institutions. For Nigeria, the Nigeria Centre for Disease Control (NCDC), charged with the said responsibility, faces a worrisome myriad of backlash from citizens' who regard their daily update of confirmed cases as misleading. In this survey, the researchers purposively study this category of sceptic individuals to understand their level of awareness of the virus and their perceptions about the government agency, to determine the factors responsible for the lack of confidence in the reportage, and how their confidence level may be boosted. The study adopted a mixed-method to recruit some 425 respondents that fit the profile of 'those who lack confidence in the NCDC daily reports'. Findings revealed that even the aware, educated, and high-income Nigerians equally constitute those with misperceptions and scepticism about the NCDC. Key reasons for the distrust include inconsistent reporting, secrecy about patients' database, and perceived corruption tendencies. Recommendations based on the findings call for increased openness and access to compelling information about activities to curtail the infection, especially transparency in treatment and budget spending.
\end{abstract}

Keywords: Covid-19 Awareness; Covid-19 Perceptions; NCDC Distrust; Covid19 Management; Covid-19 Information.

\section{INTRODUCTION}

Reportedly originating in bats, the recent outbreak of the deadly Coronavirus, otherwise called COVID-19, started in Wuhan, China, and was first reported by Chinese officials in December 2019. By February 2020, the virus found its way into Europe and North America. Among the top five countries most hit by the virus are the United States, India, Brazil, France, and Turkey [19]. The USA leads globally in Covid19 cases with over 33 million confirmed cases as of May 12, 2021 [19]. Due to the continuous spread of the virus to other Continents, the World Health Organization declared the crisis a pandemic. As of May 12 2021, the total number of confirmed cases globally stood at $160+$ Million, while the total number of deaths was $3+$ Million [19].
Nigeria recorded its first case on February 7, 2020 , and 31 days later, the Federal government imposed a lockdown on Lagos, Abuja, Ogun, and later on Kano States, while Governors of other States followed suit in efforts to limit the spread of the virus. Within this period, the country saw an increasing level of distrust among some Nigerians regarding the accuracy of the daily reportage of confirmed cases by the Nigeria Centre for Disease Control (NCDC), and this was evident in the series of criticisms and public outcries against the government, particularly on social media platforms.

Considering that it is nearly a decade since the country witnessed a public health crisis of this nature, the last one being the 1918 Influenza pandemic, there are not many perception types of research that give insight on Nigerians' societal reactions towards government and its 
agencies in periods of epidemics. While studies such as $[15,16]$ help understand general public perceptions about the virus, this one sought to narrow down the study scope to Nigerians in the Federal Capital Territory. They lack confidence in the NCDC, hoping to unravel why and what needs to be done to boost public confidence in the agency and its ability to manage the health crisis.

\section{Research Questions}

1. What is the level of Covid-19 awareness among Nigerians who are doubtful of NCDC reportage?

2. What are the factors responsible for the hesitancy towards NCDC by this select group of Nigerians?

3. What may be done to boost the confidence level of citizens regarding the transparency of NCDC in handling issues about the Covid-19 virus?

\section{Literature Review}

Despite the newness of this common enemy, Covid-19, there has been a remarkable number of articles, reports and studies that seek to broaden the general understanding of this phenomenon. Researchers [14] warn that Africa is at a high risk of a widespread infection based on weak healthcare systems, inadequate surveillance and laboratory capacity, scarcity of public health human resources, limited financial means and thus called for a unified Continentwide strategy for preparedness and response.

In contrast, authors [2] carried out a study on the early transmission dynamics of Coronavirus in Nigeria, using a 45-day estimate. Their findings suggested that cases of COVID-19 in Nigeria have been remarkably lower than expected; however, the level of preparedness to detect cases needs to be improved upon to stop local transmission.

From an economic impact perspective, author [17] argues that the spill-over of the Covid-19 pandemic to Nigeria coupled with the structural weaknesses in Nigeria's infrastructure will lead to severe economic crises if a reconstruction and development programme for the country is not implemented.

Authors [15] sought to understand the public knowledge and perception about the virus in Nigeria. Their findings revealed the Nigerian public's negative perceptions of COVID-19 bears implications across public health initiatives, compliance with preventive behaviour, and bilateral relations with foreign nations. The researchers called for an intensified evidencebased campaign to remove misconceptions and promote preventive measures. Though another study on vaccine hesitancy in Nigeria indicated a high willingness rate by respondents to accept the vaccine, their findings impress the public's need to reassure the public that any vaccine that becomes available is safe and effective [1].

Despite the series of backlash on the NCDC by several Nigerians for purporting daily figures, researchers [13] carried out public health emergency preparedness assessment towards the COVID-19 outbreak. They opined that the NCDC is steadfast, efficient and capable of curtailing the spread of COVID-19 in the Country. The study, however, did not extend its inquiry to attest to the transparency and timely information output of the NCDC to Nigerian citizens.

\section{Theoretical Framework}

Theories help researchers systematically give a clear explanation of realities based on objective and sustained propositions. This study adopts the Perception Media Theory to explain why some Nigerians remain 'negative' towards Covid19 and the NCDC news despite the heavy influx of coverage in the media (Radio, Television, Newspapers, Social Media Platforms, and Websites). Proponents of the limited-effect perspective of the mass media, a perspective within which this theory falls, argue that the media does not have a maximum universal and uniform effect on its audience. This view came alive when a 1994 study titled "The People's Choice: How the Voter Makes up His Mind in a Presidential Campaign" by Paul Lazersfeld and his associates revealed that factors such as age, sex, social interactions, beliefs all serve as intervening variables that determine how individuals receive, process and respond to communication messages. The Perception theory explains how people often interpret facts and realities to suit their pre-existing biases (beliefs, notions, judgements) [8]. When people hear what they want to hear, see what they want to see, recall what they want to recall, they result in interpreting information in ways that conform with their existing values and accepting new ideas, realities, and innovations becomes a problem. Author [8] better puts this view into perspective in the explanation of the media selectivity processes below [8]. 
Selective Exposure. People seek out information that caters for their interests, confirms their beliefs, and boosts their ego while avoiding those that are contrary to their predispositions and attack their self-image and determines which papers they subscribe to or read at all, which television stations they turn to, and which programmes they watch on those channels.

Selective Attention. The eye processes information much faster than the brain can interpret. The human brain has to select which information to pay attention to at any given time to avoid confusion.

Selective Perception. Each of us tends to perceive and then decode communication messages in light of our previous experiences and current dispositions, needs, moods, and memories. The language we speak and the words we use also tend to circumscribe our perception.

Selective Retention. We more accurately remember messages favourable to our self-image than unfavourable messages.

These principles of selective exposure, attention, perception and retention give an insight to the divergent interpretations, conscious negative attitudes, and conspiracy theories about the NCDC and Coronavirus in Nigeria by Nigerians. Based on the tenets of Selective Exposure, Attention, Perception and Retention, it becomes understandable how the people are limited to NCDC information as put out by the selected media they choose to expose themselves and pay attention to and take up such information selectively. In essence, the cascades of news from these media sources do not automatically lead them to the formation of positive perceptions of NCDC management of Covid-19 matters.

\section{METHODOLOGY}

This study employed the purposive and snowball (referred participants) sampling techniques to interview and recruit some 425 respondents within the F.C.T.

Advertisements were made on social networking sites (Facebook, Twitter, WhatsApp, and Nairaland.com) to pre-interview and then recruit those willing to partake in the survey. The samples were carefully selected to ensure they fit the profile of those who lack confidence in the NCDC daily reportage of confirmed Covid-19 cases in Nigeria. After that, it was tested in an online pilot study of 21 social media users, different from the 425 respondents later recruited. Descriptive statistics involving tables, charts, percentage distributions and frequency patterns are used to analyze the outcome of the responses from the questionnaires.

\section{RESULTS AND DISCUSSION}

Findings were classified into sections: Bio-data, News Source, Knowledge and Awareness Level and Respondents' Perceptions. Analysis of data was undertaken using frequency tables and percentages to determine significant findings.

Section A. Bio-data

Table 1

\begin{tabular}{|c|c|c|}
\hline Variable & Frequency & $\%$ \\
\hline Age & & \\
\hline $10-19$ & 21 & 4.9 \\
\hline $20-29$ & 182 & 42.8 \\
\hline $30-39$ & 81 & 19.1 \\
\hline $40-49$ & 86 & 20.2 \\
\hline $50-59$ & 50 & 11.8 \\
\hline 60 and Above & 5 & 1.2 \\
\hline Total & 425 & 100 \\
\hline Education & & \\
\hline Secondary & 40 & 9.4 \\
\hline Diploma & 25 & 5.9 \\
\hline Bachelor's Degree/HND & 263 & 61.9 \\
\hline Master's Degree & 81 & 19.1 \\
\hline PhD/Doctoral & 16 & 3.8 \\
\hline Total & 425 & 100 \\
\hline Occupation & & \\
\hline Civil Servant & 86 & 20.2 \\
\hline Artisan & 20 & 4.7 \\
\hline Self-employed & 142 & 33.4 \\
\hline Trader & 41 & 9.6 \\
\hline Industrialist & 24 & 5.6 \\
\hline N.G.O. & 4 & 9 \\
\hline Unemployed & 61 & 14.4 \\
\hline Student & 47 & 11.1 \\
\hline Total & 425 & 100 \\
\hline Geographical Location & & \\
\hline Abaji & 11 & 2.6 \\
\hline Abuja Municipal & 102 & 24 \\
\hline Bwari & 140 & 32.9 \\
\hline Gwagalada & 71 & 16.7 \\
\hline Kuje & 58 & 13.6 \\
\hline Kwali & 43 & 10.1 \\
\hline Total & 425 & 100 \\
\hline Average Monthly Income & & \\
\hline Less than N50,000 & 67 & 15.8 \\
\hline $\mathrm{N} 50,000$ to $\mathrm{N} 100,000$ & 120 & 28.2 \\
\hline $\mathrm{N} 100,000$ to $\mathrm{N} 150,000$ & 104 & 24.5 \\
\hline $\mathrm{N} 150,000$ to $\mathrm{N} 200,000$ & 86 & 20.2 \\
\hline $\mathrm{N} 200,000$ to $\mathrm{N} 250,000$ & 41 & 9.6 \\
\hline N250,000 and Above & 7 & 1.6 \\
\hline Total & 425 & 100 \\
\hline
\end{tabular}


The age distribution shows that the majority of the respondents are between the ages of 20-29 (42.8\%) of the entire sample, thus corroborating the 2018 statistics from Pew Research Centre, that of all age groups, 18-29 year-olds drive most of the social media consumption globally. Respondent's levels of education were needed to understand its possible influence on the perception of Covid-19 management by the NCDC in Nigeria. Findings show that majority of the respondents are educated, at least by general societal standards, with 236 (61.9\%) of them possessing Bachelor's/HND degree, and 19\% and $3.8 \%$ of them respectively being Master's and Doctoral degree holders.

Many studies, such as [5], find that employees are most affected by the pandemic. Likewise, a US study on vaccine acceptance noted that employed persons have a stake and are more likely to accept covid-19 vaccinations, perhaps to avoid job losses willingly but tended to trust more the information on Covid-19 from their healthcare professionals and officials [12]. In essence, employees are more likely to develop concerns about the management of the virus. This assertion is justified in the above occupation distribution, where most respondents $(74 \%$ a summation of all employed respondents) are employed, with only $14.4 \%$ unemployed and $11 \%$ students.

The Nigerian National Population Commission puts the total population of F.C.T to 1.4 million, with the more significant percentages of that population residing in Abuja Municipal, Bwari, and Gwagwalada. This very much tallies with the figures arrived at in the above table as respondents are representative of the leading communities of the F.C.T. Although studies like $[4,7]$ show how poverty is viewed as a factor behind the disbelief in the Covid-19 pandemic in Nigeria, data from the above table shows that majority of the respondents earn above the $\$ 1.90$ (N725) daily international poverty line set by the World Bank [21].

Section B. Sources of Covid-19 and NCDC News for Respondents

As expected, social media (18.3\%), then Television (15.9\%) and Radio (13.5\%) took the lead in that order on the most common source for Covid-19 news stories by respondents. With close Friends (12.2\%), News Websites (12.1\%) and Online Forums (11\%) trailing behind. Data from this chart indicates that people are less likely to rely on their religious leaders $(1.2 \%)$ for information about the virus (Figure 1).

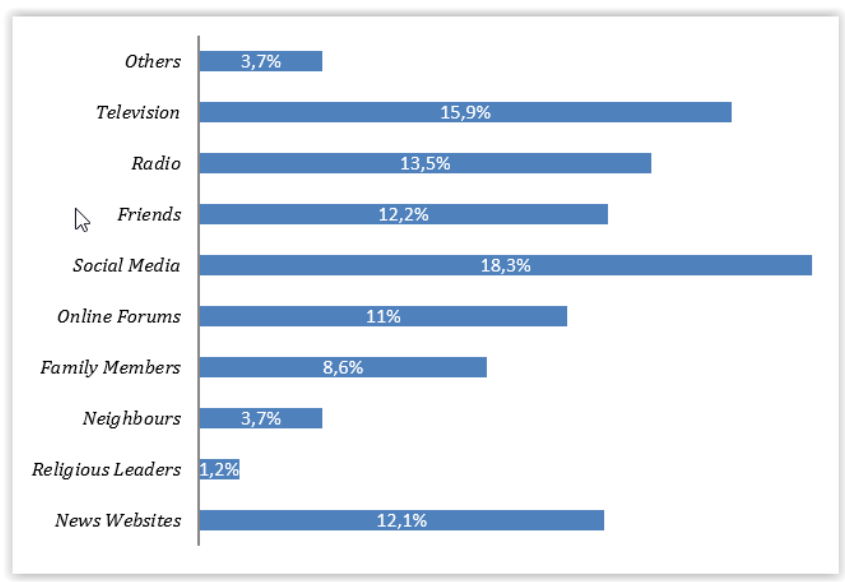

Figure 1 - Sources of Covid-19 and NCDC News for Respondents

Authors [3] find that reliance on social media for news is one reason fake news and unhealthy attitude and practices towards the virus are prevalent. They further contend that unregulated social media may present a health risk that is partly but not wholly reducible to their role as disseminators of health-related conspiracy beliefs when used as an information source. A comparative study in Pakistan portrayed the media as responsible for disseminating and amplifying narratives of conspiracy theories that led to hitherto failed immunization programmes and capable of resulting in health risks in managing Covid-19 [10].

The earlier referred US study showed that only a few participants reported Social Media as a reliable source of Covid-19 information [12]. The higher use of social media by our respondents may not be unconnected with the poor availability of news from traditional media and healthcare professionals during the pandemic.

\section{Section C. Knowledge \& Awareness Level}

To determine how the level of knowledge and awareness about the virus may affect the respondents' perceptions towards its management by the NCDC, a series of basic questions about transmission, symptoms and preventive measures were set. Responses retrieved indicate that most respondents' scepticism towards the NCDC reportage of Covid19 issues management is not due to lack of knowledge or awareness about the virus (Table 2). 
Table 2

\begin{tabular}{|c|c|c|}
\hline Variable & Frequency & $\%$ \\
\hline $\begin{array}{r}\text { Currently, Covid-19 is a } \\
\text { worldwide disease }\end{array}$ & & \\
\hline 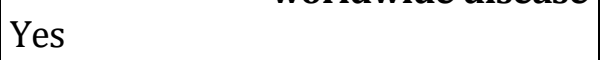 & 300 & 300 \\
\hline No & 51 & 51 \\
\hline I don't know & 74 & 74 \\
\hline Total & 425 & 425 \\
\hline $\begin{array}{l}\text { One of the following is not how } \\
\text { Covid-19 is transmitted }\end{array}$ & & \\
\hline Person to Person Contact & 0 & 0 \\
\hline Droplets from coughing, sneezing & 0 & 0 \\
\hline Touching contaminated surfaces & 0 & 0 \\
\hline Frequent exposure to sun & 425 & 425 \\
\hline Total & 425 & 42 \\
\hline $\begin{array}{l}\text { The virus is most deadly among } \\
\text { people with pre-existing health } \\
\text { conditions }\end{array}$ & & \\
\hline Agree & 425 & 100 \\
\hline Disagree & 0 & 0 \\
\hline Total & 425 & 100 \\
\hline $\begin{array}{l}\text { One of the following is not a } \\
\text { preventive measure against }\end{array}$ & & \\
\hline Social Distancing & 0 & \\
\hline Washing Hands Regularly & 0 & 0 \\
\hline Using Hand Sanitizers & 0 & 0 \\
\hline Push-Ups and Weightlifting & 425 & 10 \\
\hline Total & 425 & 10 \\
\hline $\begin{array}{r}\text { One of the following is not a } \\
\text { symptom of the virus }\end{array}$ & & \\
\hline Nose bleeding & 425 & 100 \\
\hline Fever & 0 & 0 \\
\hline Shortness of breath & 0 & 0 \\
\hline Cough & 0 & 0 \\
\hline Total & 425 & 100 \\
\hline
\end{tabular}

\section{Section D. Respondents' Perceptions}

The following Table 3 is a multiple response table with eight categories that attempt to capture the perception of the respondents, mainly the reasons behind their scepticism towards NCDC reportage of the virus.

In the first column, all 425 respondents disagree that Covid-19 is a hoax. In the same vein, some $40(9.4 \%)$ agree that although the virus exists elsewhere, it doesn't work in Nigeria. Some 265 (62\%) agree that the covid-19 case numbers are being bloated by the NCDC, while 263 (61\%) say their disbelief is tied to the fact that they do not personally know anyone with the virus since its inception. While 281 (66\%) worry that NCDC attributes all deaths, even unrelated ones, to Covid19, some $243(57.2 \%)$ believe that the NCDC is bloating Covid-19 figures to embezzle public funds. On the rather extreme side, some $202(47.5 \%)$ agree that covid-19 test kits are tampered with by the NCDC to produce falsepositive results.

Table 3

\begin{tabular}{|l|c|c|c|c|}
\hline \multirow{2}{*}{ Popular Viewpoints } & \multicolumn{2}{|c|}{ Agree } & \multicolumn{2}{c|}{ Disagree } \\
\cline { 2 - 5 } & (F.R.Q.) & (\%) & (F.R.Q.) & (\%) \\
\hline $\begin{array}{l}\text { Covid-19 is a hoax; it } \\
\text { doesn't exist } \\
\text { anywhere }\end{array}$ & 0 & 0 & 425 & 100 \\
\hline $\begin{array}{l}\text { Covid-19 exists, but } \\
\text { not in Nigeria }\end{array}$ & 40 & 9.4 & 385 & 90.6 \\
\hline $\begin{array}{l}\text { Covid-19 exists in } \\
\text { Nigeria, but NCDC is } \\
\text { bloating the figures }\end{array}$ & 265 & 62.4 & 160 & 37.6 \\
\hline $\begin{array}{l}\text { I don't believe the } \\
\text { NCDC figures } \\
\text { because I don't } \\
\text { personally know } \\
\text { anyone with the } \\
\text { virus }\end{array}$ & 263 & 61.9 & 162 & 38.1 \\
\hline $\begin{array}{l}\text { NCDC attributes all } \\
\text { deaths to Covid19, } \\
\text { even those that died } \\
\text { of other illnesses }\end{array}$ & 281 & 66.1 & 144 & 33.9 \\
\hline $\begin{array}{l}\text { The NCDC is } \\
\text { bloating Covid-19 } \\
\text { figures to embezzle } \\
\text { public funds }\end{array}$ & 243 & 57.2 & 182 & 42.8 \\
\hline $\begin{array}{l}\text { The test kits are } \\
\text { tampered with, such } \\
\text { that all test } \\
\text { conducted comes } \\
\text { out as positive }\end{array}$ & 202 & 47.5 & 223 & 52.5 \\
\hline $\begin{array}{l}\text { The daily figures are } \\
\text { inconsistent; this is } \\
\text { why I don't believe } \\
\text { the NCDC }\end{array}$ & 304 & 71.5 & 121 & 28.5 \\
\hline
\end{tabular}

Perhaps, this lack of overwhelming confidence in the operations of a Country's health Institution managing the virus is implied elsewhere in the US study by [12] where only $67 \%$ of study participants had the highest confidence in the Centre for Disease Control (C.D.C.) compared to $75 \%$ confidence level for healthcare professionals who, in their estimation, are the "most reliable sources of information on COVID19".

From the table 3, the inconsistent nature of the daily figures released by NCDC is why the majority $(71.5 \%)$ of the respondents' lack confidence in the NCDC reportage. This can be linked to the sometimes irregular rise and fall of 
daily figures and the several instances where there were discrepancies in the report by individual State Ministries and the NCDC. Some respondents cited the stagnant situation in Kogi State - Nigeria, where NCDC officials have reported only five cases of the infection since the beginning of the pandemic to date as justification of their viewpoint [20].

Discussion question 1: What is the level of Covid19 awareness among Nigerians doubtful of NCDC reportage?

Findings from this study indicated that despite the lack of confidence in the NCDC reportage, all the respondents recruited have essential awareness about the virus. This finding contrasts with [18], who view that health literacy, particularly in this pandemic era, helps the public grasp the reasons behind experts' recommendations and reflect on their outcomes various possible actions. Findings here show that health literacy as a single factor does not necessarily counter peoples' misperceptions as the case may be.

Discussion question 2: What are the factors responsible for the hesitancy towards NCDC by the select Nigerians?

As earlier reported, 62\% $(n=263)$ of the 425 respondents say their disbelief is tied to the fact that they do not personally know anyone infected with the virus since its inception, 57\% $(n=243)$ others agree that the NCDC, in collaboration with other government officials are out to embezzle public funds. While the former could be credited to personal covid-19 experience gaps, the latter describes the common Nigerian notion that every government administration, whether past, present or future, are out to satisfy selfish interests. Corroborating this notion is authors [9], who argue that Nigeria has lost traction in its attempt to achieve national development because of the unfair climate of "chop-I-chop" politics, ethnicity, mediocrity, partisanship, cronyism, corrupted process of recruitment of leaders, among other factors [9].

The Kogi State Government out-rightly accused the P.T.F. of being "hell-bent in squandering over \$1Billion in the procurement of COVID-19 vaccines" (where the high success rate of treatment of patients has been without vaccines) rather than more pressing health issues like maternal mortality [20]. However, this should not hold sway for the importance of administering COVID-19 vaccines as a step to curtail the virus's rage. These results corroborate the study by [16], who found that 324 participants $(86.63 \%)$ of their respondents think the government is using the avenue to siphon public funds. In comparison, some 223 Participants (59.62\%) think the government has the wrong test kit and probably diagnoses something else due to the excellent recovery rate and low death to infection ratio. The same study also found that the composition of the Presidential Task Force against Covid-19 mainly comprises of Politicians rather than Career Research Scientists, Virologist or Statistical/Mathematical Modellers compared to task-forces of other nations [16].

Discussion question 3: What may be done to boost the confidence level of citizens towards the transparency of NCDC in handling the virus?

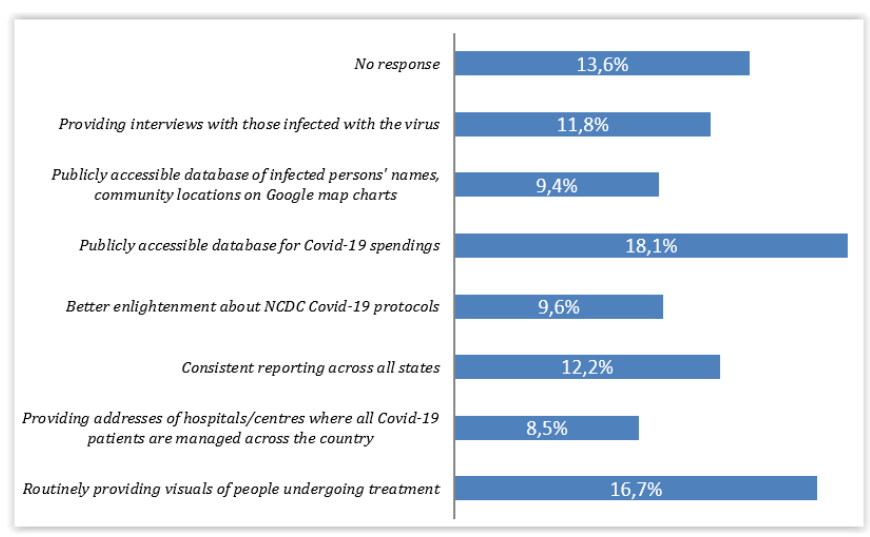

Figure 2

A famous proverb reads that 'seeing is believing. This notion plays out in this study, as shown above in Figure 2, where $16.7 \%$ and $11.8 \%$ of respondents respectively suggest routine visuals and interviews with people undergoing treatment. Some $8.5 \%$ others further suggested providing information about hospitals and health institutions/centres where all covid-19 patients are managed. In the same vein, some $9.4 \%$ of the respondents opined that the availability of a publicly accessible database of infected persons, their names, community locations on Google map would foster public trust. The issue of privacy associated with personal health information may arise here concerning the provision of names of infected persons. While $12.2 \%$ of respondents suggest that credibility is increased when daily case numbers reported are consistent across the States, another $9.6 \%$ call for better 
enlightenment about the NCDC day-to-day activity and protocol as a means to understand their workflow better.

A significant conspiracy about Covid-19 in Nigeria, as can be seen from responses thus far, is that the NCDC is bloating Covid-19 figures to embezzle public funds, that is; the higher the case numbers, the higher the monetary budgets for fighting the virus, and the higher the chances of these monies getting embezzled. So, $18 \%$ of the respondents recommend providing a publicly accessible database for Covid-19 spending in the country to boost public confidence and trust in the fight against Coronavirus in Nigeria. The U.S. health Institution, C.D.C., transparently displays updated activity and spending details on the website and the media. Nevertheless, these results point to the need for a high level of trust in NCDC if COVID-19 protocols and vaccines to curtail the virus infection will be accepted by Nigerians. Other findings have thrown up results indicating that respondents who reported high levels of trust in information from government sources were more likely to accept a health recommendation for a vaccine [11]. The NCDC will need to take a cue from this recommendation to manage the virus henceforth.

\section{CONCLUSION}

Based on the results of this study, it is apparent that Nigerians at all levels, even the educated and well-to-do equally, constitute those with misperceptions and nurture scepticism towards the Federal government and NCDC reportage and management of Covid-19 in Nigeria. Glaringly, some of these reservations are borne out of some government inadequacies in managing the virus with its adverse impact.

The study, therefore, recommends a review of the constitution and guiding principles of Covid19 Presidential Taskforce (P.T.F.) to include more experts; increased openness and access to influential information about patients undergoing treatment, consistent and wellharmonized daily case reportage and public reassurance on the sincerity of purpose by providing up-to-date records on Covid-19 spending. Majorly, effective implementation of these recommendations involves Government and its Health Agencies establishing a synergy with the news media- print, broadcast and social for gathering, authenticating and disseminating required information.

\section{REFERENCES}

1. Adebisi, Y. A., Alaran, A. J., Bolarinwa, O. A., Akande-Sholabi, W., \& Lucero-Prisno, D. E. (2020). When it is available, will we take it? Public perception of hypothetical COVID-19 vaccine in Nigeria. doi: 10.1101/2020.09.24.20200436

2. Adegboye, O. A., Adekunle, A. I., \& Gayawan, E. (2020). Early Transmission Dynamics of Novel Coronavirus (COVID-19) in Nigeria. International Journal of Environmental Research and Public Health, 17(9), 3054. doi: 10.3390/ijerph17093054

3. Allington, D., Duffy, B., Wessely, S., Dhavan, N., \& Rubin, J. (2020). Health-protective behaviour, social media usage and conspiracy belief during the COVID-19 public health emergency. Psychological Medicine, 1-7. doi: 10.1017/s003329172000224x

4. Bargain, O., \& Aminjonov, U. (2020). Trust and compliance to public health policies in times of COVID-19. Journal of Public Economics, 192, 104316. doi: 10.1016/j.jpubeco.2020.104316

5. Brewer, M., \& Gardiner, L. (2020). The initial impact of COVID-19 and policy responses on household incomes. Oxford Review of Economic Policy, 36, S187-S199. doi: 10.1093/oxrep/graa024

6. Centers for Disease Control and Prevention. (2021). United States COVID-19 Cases, Deaths, and Laboratory Testing (NAATs) by State, Territory, and Jurisdiction. Retrieved April 1, 2021, from https://covid.cdc.gov/covid-data-tracker/\#cases_casesper100klast7days

7. Chukwuorji, J. C., \& Iorfa, S. K. (2020). Commentary on the coronavirus pandemic: Nigeria. Psychological Trauma: Theory, Research, Practice, and Policy, 12(S1), S188-S190. doi: $10.1037 /$ tra0000786

8. Folarin, B. (1998). Theories of Mass Communication: An Introductory Text. Ibadan: Stirling-Horden Publishers. 
9. Imhonopi, D., \&Ugochukwu, M. (2013). Leadership Crisis And Corruption in the Nigerian Public Sector: An Albatross of National Development. The African Symposium, 13(1), 78-87.

10. Khan, Y. H., Mallhi, T. H., Alotaibi, N. H., Alzarea, A. I., Alanazi, A. S., Tanveer, N., \& Hashmi, F. K. (2020). Threat of COVID-19 Vaccine Hesitancy in Pakistan: The Need for Measures to Neutralize Misleading Narratives. The American Journal of Tropical Medicine and Hygiene, 103(2), 603-604. doi: 10.4269/ajtmh.20-0654

11. Lazarus, J. V., Ratzan, S. C., Palayew, A., Gostin, L. O., Larson, H. J., Rabin, K., ... El-Mohandes, A. (2020). A global survey of potential acceptance of a COVID-19 vaccine. Nature Medicine, 27(2), 225-228. doi: 10.1038/s41591-020-1124-9

12. Malik, A. A., McFadden, S. M., Elharake, J., \& Omer, S. B. (2020). Determinants of COVID-19 vaccine acceptance in the US. EClinicalMedicine, 26, 100495. doi: 10.1016/j.eclinm.2020.100495

13. Mustapha, J., Adedokun, K., \& Nasir, I. (2020). Public health preparedness towards COVID-19 outbreak in Nigeria. Asian Pacific Journal of Tropical Medicine, 13(5), 197. doi: 10.4103/19957645.279650

14. Nkengasong, J. N., \& Mankoula, W. (2020). Looming threat of COVID-19 infection in Africa: act collectively, and fast. The Lancet, 395(10227), 841-842. doi: 10.1016/s0140-6736(20)30464-5

15. Olapegba, P. O., Ayandele, O., Kolawole, S. O., Oguntayo, R., Gandi, J. C., Dangiwa, A. L., ... Iorfa, S. K. (2020). COVID-19 Knowledge and Perceptions in Nigeria. doi: 10.31234/osf.io/j356x

16. Oluwaseyi, I., Jokotola P., \& Alebiosu, O. E. (2020). To Trust or Distrust; Constant Dilemma of Nigerian Populace During Pandemics - The Case Of The Coronavirus Disease Of 2019 (Covid-19). Retrieved from https://doi.org/10.6084/m9.figshare.12401486.v1

17. Ozili, P. K. (2020). COVID-19 Pandemic and Economic Crisis: The Nigerian Experience and Structural Causes. SSRN Electronic Journal. doi: 10.2139/ssrn.3567419

18. Paakkari, L., \& Okan, O. (2020). COVID-19: health literacy is an underestimated problem. The Lancet Public Health, 5(5), e249-e250. doi: 10.1016/s2468-2667(20)30086-4

19. Statista. (2021). COVID-19/Coronavirus. Facts and Figures. Retrieved from https://www.statista.com/page/covid-19-coronavirus

20. The Nation. (2021, February 5). Kogi State Government's response to the reckless Comments credited to the Presidential Task Force on Covid with respect to Kogi State. Retrieved from https://thenationonlineng.net/kogi-state-governments-response-to-the-reckless-commentscredited-to-the-presidential-task-force-on-covid-with-respect-to-kogi-state/

21. World Bank Group. (2020). Poverty and Shared Prosperity 2020. Reversals of Fortune. Retrieved from https://www.worldbank.org/en/publication/poverty-and-shared-prosperity 